\title{
Mechanisms of Resistance to Fusidic Acid in Staphylococcus aureus
}

\author{
By I. CHOPRA \\ Department of Bacteriology, The Medical School, University of Bristol, \\ Bristol BS8 ITD
}

(Received 17 March 1976; revised 9 May 1976)

\begin{abstract}
SUMMARY
The biochemical mechanisms of resistance to fusidic acid in Staphylococcus aureus were investigated. Organisms possessing plasmid genes for resistance showed a high basal level of resistance, but could be induced to higher levels after pre-incubation with fusidic acid. This induction occurred rapidly and probably did not depend on gene dosage effects. Mutants resistant to fusidic acid, obtained from plasmid-negative cultures, expressed resistance constitutively. Protein synthesis in cell-free extracts from staphylococci with plasmid-mediated resistance to fusidic acid was as sensitive to fusidic acid as was synthesis in preparations from sensitive organisms; whereas protein synthesis in preparations from a spontaneous fusidic acid resistant mutant was resistant to the antibiotic. None of the resistant strains caused detectable inactivation of fusidic acid and no new derivative of fusidic acid was found in culture extracts of plasmid-possessing organisms grown in the presence of radioactive antibiotic. Expression of plasmid-mediated resistance to fusidic acid was associated with a decrease in the molar ratio of phosphatidylglycerol to lysylphosphatidylglycerol, but the cardiolipin content remained constant.
\end{abstract}

\section{INTRODUCTION}

Fusidic acid is a steroid antibiotic that prevents protein synthesis by inhibiting functions associated with translocation factor protein (factor $G$ or EFG). Binding of fusidic acid to factor $G$ stabilizes the association of the ribosome-factor-G-GDP complex and inhibits the binding of aminoacyl tRNA to the ribosome (Bodley et al., 1969; Richman \& Bodley, 1972). Elongation of nascent polypeptides is therefore prevented. Although Escherichia coli is intrinsically relatively resistant to the antibiotic, chromosomal mutants with increased resistance are readily obtained in vitro. Such mutants invariably have a modified factor G (Kinoshita, Kawano \& Tanaka, I968; Bernardi \& Leder, 1970; Okura, Kinoshita \& Tanaka, I970; Tanaka, Kawano \& Kinoshita, 1971) which has decreased affinity for fusidic acid (Okura et al., 1970).

Fusidic acid is particularly active against Staphylococcus aureus and has been used to treat staphylococcal infections - often after other measures have failed (Garrod, Lambert \& O'Grady, 1973). However, since spontaneous mutation to fusidic acid resistance in $S$. aureus occurs at high frequency in vitro (Miller, 1971 ; Lacey \& Grinsted, 1972) and because resistant staphylococci have sometimes been isolated after therapy (Lowbury et al., 1962), fusidic acid is usually administered in combination with other antibiotics, particularly the penicillins (Garrod et al., 1973).

Although the emergence of staphylococci that are resistant to both antibiotics, following such combined therapy, is comparatively rare (Pattison \& Mansell, 1973), some have been isolated. In these organisms, the genes specifying resistance to fusidic acid are either

Vol. 96, No. 1, was issued 23 September 1976 
Table I. Characteristics of bacterial strains

\begin{tabular}{|c|c|c|c|c|c|}
\hline Strain & Genotype* & $\begin{array}{l}\text { Mol. wt of } \\
\text { penicillinase } \\
\text { plasmid } \\
\text { (mega- } \\
\text { daltons) } \dagger\end{array}$ & $\begin{array}{l}\text { M.i.c. of } \\
\text { fusidic acid } \\
\left(\mu \mathrm{g} \mathrm{ml}^{-1}\right)\end{array}$ & $\begin{array}{c}\text { Mean } \\
\text { generation } \\
\text { time (min) } \ddagger\end{array}$ & $\begin{array}{c}\text { Phage typing } \\
\text { pattern } \\
\text { (RTD)§ }\end{array}$ \\
\hline UB400 I & pUBIOI & 16 & IO & 27 & $3 \mathrm{~A}$ \\
\hline UB4002 & pUBIOI $^{-}$ & - & 0.25 & 23 & $3 \mathrm{~A}$ \\
\hline UB4003 & pUBiol- fus-I & - & 10 & 23 & $3 \mathrm{~A}$ \\
\hline UB4004 & $\mathrm{pUBIOI}^{-}$fus-2 & - & 30 & 28 & $3 \mathrm{~A}$ \\
\hline UB4005 & pUBIoI- fus-3 & - & 75 & 29 & $3 \mathrm{~A}$ \\
\hline UB4006 & pUBIor- $f u s-4$ & - & I 50 & 64 & $3 \mathrm{~A}$ \\
\hline UB4045 & pUBI ${ }_{3}$ & 16 & 10 & 23 & $3 \mathrm{~A}$ \\
\hline UB4057 & pUBII 7 & 15 & 0.25 & 23 & $3 \mathrm{~A}$ \\
\hline
\end{tabular}

* Plasmid pUBior specifies resistance to penicillin, fusidic acid and cadmium ions. Plasmid pUBir3 specifies resistance to penicillin (low-level), fusidic acid and cadmium ions and is derived from plasmid pUBior (see Lacey et al., 1974). Plasmid pUBI 7 specifies resistance to penicillin (low-level) and cadmium ions only, being derived from plasmid pUBi13 by deletion of the locus specifying fusidic acid resistance (see Lacey et al., 1974). The abbreviations fus-I to fus-4 denote resistance to fusidic acid which has arisen by spontaneous mutation.

$\uparrow$ Determined from sedimentation data in sucrose gradients (see Lacey et al., 1974). The molecular weight of pUBior estimated by contour length measurement is $14^{.6}$ megadaltons (Chopra et al., 1973).

$\ddagger$ Performed at $37^{\circ} \mathrm{C}$ and determined from semi-logarithmic plots of culture turbidity at $675 \mathrm{~nm}$ versus time. Values quoted are the mean of at least four separate determinations for each strain. Growth rates for strains UB400I, UB4045 and UB4057 were determined in the presence of $10^{-4} \mathrm{M}-\mathrm{CdCl}_{2}$ (see text).

$\S \mathrm{RTD}$, routine test dilution.

chromosomal (Pattison \& Mansell, 1973; Lacey \& Rosdahl, 1974), or plasmid located (Evans \& Waterworth, I966; Lacey \& Grinsted, 1972; Lacey \& Rosdahl, 1974). In a recent survey of staphylococci obtained from several sources, the genes coding for fusidic acid resistance comprised part of a 'penicillinase-fusidic acid' (PF) plasmid in $70 \%$ of strains that were resistant to both penicillin and fusidic acid (Lacey \& Rosdahl, 1974). Since the properties of each of these PF plasmids appear to be similar, it is probable that a single PF plasmid has spread among several types of $S$. aureus in nature (Lacey \& Rosdahl, 1974; Lacey, 1975).

Because the frequency of 'chromosomal' mutation to fusidic acid resistance is high (at least in vitro), the relative predominance of staphylococci possessing plasmid-mediated resistance to fusidic acid is puzzling. This situation could be related to the mechanism of resistance mediated by chromosomal and plasmid genes. In this paper it is shown that the mechanism of plasmid-mediated resistance to fusidic acid does differ from that mediated by chromosomal mutation.

\section{METHODS}

Strains of Staphylococcus aureus. The strains used are described in Table I. Strain UB400I is a clinical isolate (formerly designated FAR4) or iginally described by Lacey \& Grinsted (I972): it contains plasmid pUBIor which specifies resistance to penicillin, fusidic acid and cadmium ions (i.e. a PF plasmid). Strain UB4002 was derived from UB400I by growth of the latter at $43{ }^{\circ} \mathrm{C}$, which resulted in loss of pUB Ior (Lacey \& Grinsted, 1972). Strains UB4003 to UB4006 were spontaneous one-step fusidic acid resistant mutants derived from UB4002 by selection on media containing fusidic acid. The origins of UB4045 and UB4057 have been described previously (Lacey, Lewis \& Rosdahl, 1974). 
Chemicals. Uniformly ${ }^{14} \mathrm{C}$-labelled L-amino-acid mixture $(54 \mathrm{mCi} / \mathrm{mmol}$ of $\mathrm{C}), \mathrm{L}-\left[\mathrm{G}-{ }^{3} \mathrm{H}\right]-$ phenylalanine (I mCi $\mu \mathrm{mol}^{-1}$ ) and $\left[2{ }^{3} \mathrm{H}\right] \mathrm{glycerol}\left(0 \cdot 143 \mathrm{mCi} \mu \mathrm{mol}^{-1}\right)$ were purchased from the Radiochemical Centre, Amersham, Buckinghamshire. [ I $\left.\beta-{ }^{3} \mathrm{H}\right] \mathrm{Fusidic}$ acid (as the diethanolamine salt; $50.53 \mu \mathrm{Ci} \mathrm{mg}{ }^{-1}$; radiochemical purity $96.8 \%$ ) was a gift from W. O. Godtfredsen of Leo Pharmaceutical Products, Denmark.

General methods. Media, detection of loss of antibiotic resistance and bacteriophage typing were performed as previously described (Lacey \& Chopra, 1974).

The minimal inhibitory concentration (m.i.c.) of fusidic acid (as the diethanolamine salt) was determined by inoculating nutrient agar plates containing various concentrations of fusidic acid with approximately 50 colony-forming units. The m.i.c. was taken as the level of antibiotic that completely inhibited growth after incubation for $24 \mathrm{~h}$ at $37^{\circ} \mathrm{C}$.

Isolation of covalently closed circular (CCC) DNA and calculation of the percentage CCC in total DNA was performed as described previously (Chopra, Bennett \& Lacey, 1973).

Estimation of protein synthesis in whole cells. Bacteria suspended in nutrient broth containing ${ }^{14} \mathrm{C}$-labelled amino acids $\left(0.3 \mu \mathrm{Ci} \mathrm{ml}{ }^{-1}\right)$ were incubated with shaking at $37^{\circ} \mathrm{C}$ for various periods. Growth was stopped by adding trichloroacetic acid to $5 \%(\mathrm{w} / \mathrm{v})$, and the incorporation of radioactivity into protein was determined as described previously (Lacey \& Chopra, 1972).

Preparation and assay of cell-free protein-synthesizing extracts. These were prepared and assayed as described previously (Lacey \& Chopra, I972), except that L-[G- $\left.{ }^{3} \mathrm{H}\right]$ phenylalanine $(20 \mu \mathrm{Ci} \mathrm{ml}-1)$ was substituted for ${ }^{14} \mathrm{C}$-labelled amino acids in the assay system.

Bioassay of fusidic acid. This was performed by the diffusion method of Grove \& Randall (I955) using $S$. aureus strain Oxford (m.i.c. $0 \cdot 2 \mu \mathrm{g} \mathrm{ml}^{-1}$ ) as indicator. Culture samples were filtered through Millipore membrane filters (type $\mathrm{HA} ; 0.45 \mu \mathrm{m}$ pore size) before the fusidic acid concentrations were determined.

Thin-layer chromatography of fusidic acid. Thin-layer chromatography plates $(20 \times 20 \mathrm{~cm})$ were prepared using a slurry of Merck silica gel $P_{254}(30 \mathrm{~g})$ in distilled water $(75 \mathrm{ml})$ to give a layer $0.25 \mathrm{~mm}$ thick. Plates were dried overnight at room temperature and activated by heating at $\mathrm{I} 10^{\circ} \mathrm{C}$ for $40 \mathrm{~min}$. Non-labelled fusidic acid, dissolved in ethanol or chloroform, was applied (10 to $20 \mu \mathrm{g}$ per spot) to activated plates which were then developed in one dimension using one of two solvents. Solvent I comprised chloroform/cyclohexane/ methanol/acetic acid (80:10:2.5:10, by vol.), and solvent 2, diethyl ether/acetic acid (I00:0.5, by vol.). Plates were generally developed to $18 \mathrm{~cm}$, dried, and then the spots were detected using iodine vapour.

Fusidic acid modification studies using radioactively labelled antibiotic. Strain UB400I (initial inoculum, $\mathrm{IO}^{2}$ organisms $\mathrm{ml}^{-1}$ ) was incubated for $18 \mathrm{~h}$ at $37^{\circ} \mathrm{C}$ in nutrient broth containing [ I I $\left.\beta{ }^{3} \mathrm{H}\right]$ fusidic acid $\left(50.53 \mu \mathrm{Ci} \mathrm{mg}^{-1}\right)$ at $\mathrm{I} \mu \mathrm{g}$ per $\mathrm{ml}$ culture. The culture (usually I6 ml) was then extracted according to the method of Bligh \& Dyer (1959). After removal of the chloroform phase, the methanol-aqueous phase was re-extracted with further portions of chloroform. The first chloroform extract contained 85 to $90 \%$ of the input radioactivity and quantitative recovery of the radioactivity was achieved by three further extractions with chloroform. The chloroform extracts were combined, concentrated to about $0.2 \mathrm{ml}$ by evaporation under vacuum and samples ( 5 to $10 \mu \mathrm{l}$ ) were chromatographed as described above.

${ }^{3} \mathrm{H}$-labelled extracts were always co-chromatographed with non-labelled fusidic acid $(20 \mu \mathrm{g})$ applied to the same lane to compensate for slight variations in mobility. Plates were developed in iodine vapour to determine the $R_{F}$ value of authentic fusidic acid. They were 

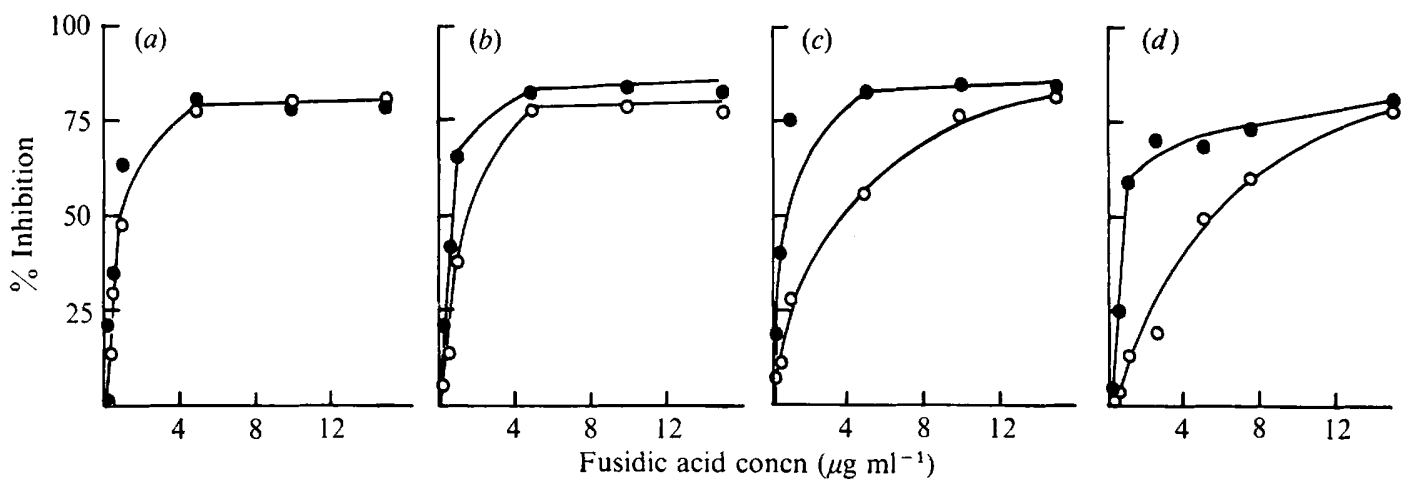

Fig. I. The effect of pre-incubation with fusidic acid on resistance to the antibiotic in UB400I, as measured by the inhibition of protein synthesis. Cultures of UB400I $\left(\mathrm{I} \times 1 \mathrm{IO}^{8}\right.$ bacteria $\left.\mathrm{ml}^{-1}\right)$ growing exponentially in nutrient broth containing $\mathrm{Cd}^{2+}$ were incubated with $(O)$ or without $(O)$ fusidic acid $\left(0.5 \mu \mathrm{g} \mathrm{ml}^{-1}\right)$ for $(a) 0.2,(b) 0.5,(c) \mathrm{I} \cdot 0$, or $(d) 2.0$ generation times. Bacteria were harvested by centrifuging (10000 $\mathrm{g}$; 10 min; $4{ }^{\circ} \mathrm{C}$ ) and washed twice with cold growth medium lacking fusidic acid. Bacteria were resuspended in fresh growth medium to a density of $\mathrm{I} \times 1 \mathrm{O}^{\mathbf{8}}$ bacteria $\mathrm{ml}^{-1}$ and their capacity to synthesize protein over a period of $40 \mathrm{~min}$ in the presence of different concentrations of fusidic acid was determined as described in Methods.

then divided into $0.5 \mathrm{~cm}$ fractions from the origin and each fraction was transferred directly to a scintillation vial. Scintillation fluid (Snyder \& Stephens, 1962) was added, and samples were counted. Recovery of ${ }^{3} \mathrm{H}$-labelled material from thin-layer plates was between 86 and $94 \%$.

Quantitative analysis of phospholipids. Cultures were grown for four generations in nutrient

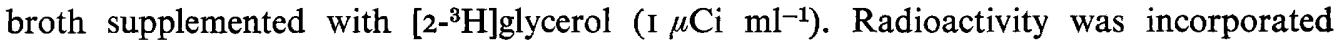
exponentially during this period. Lipids were extracted directly from the ${ }^{3} \mathbf{H}$-labelled cultures by the method of Bligh \& Dyer (1959), and concentrated under vacuum. They were separated on sodium-acetate-impregnated silica-gel plates (Minnikin \& Abdolrahimzadeh, 197I) in one dimension using chloroform/methanol/water $(65: 25: 4$, by vol.) as solvent. The separated lipids were detected using iodine vapour and the spots corresponding to the phospholipids (cardiolipin, phosphatidylglycerol and lysylphosphatidylglycerol) were transferred directly to scintillation vials and counted as described above. Individual phospholipids were identified by comparing their mobilities with authentic standards and by using spray reagents specific for phosphate esters and free amino groups (Skipski \& Barclay, I969).

\section{RESULTS}

Effect of pre-incubation with fusidic acid on resistance to the antibiotic

When UB400I was pre-incubated with fusidic acid at $0.5 \mu \mathrm{g} \mathrm{ml}^{-1}$ (a virtually noninhibitory concentration) for two generation times ( $54 \mathrm{~min}$ ), the subsequent inhibition of protein synthesis by this antibiotic was less than in organisms grown initially in the absence of fusidic acid (Fig. I $d$ ). Thus, fusidic acid at $5 \mu \mathrm{g} \mathrm{ml}^{-1}$ inhibited protein synthesis in organisms not pre-exposed to the antibiotic by about $70 \%$, whereas pre-exposed organisms showed about $50 \%$ inhibition (Fig. I $d$ ). These results are not merely due to selection of plasmid-positive organisms on exposure to fusidic acid during the pre-incubation period, since about $99 \%$ of the cocci were plasmid positive throughout. Pre-exposure of either UB400I or UB4002 to sub-inhibitory concentrations of chloramphenicol (another inhibitor 


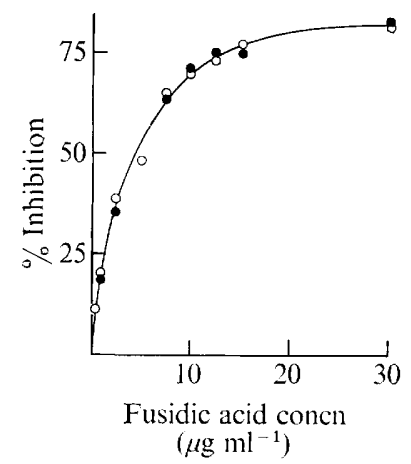

Fig. 2

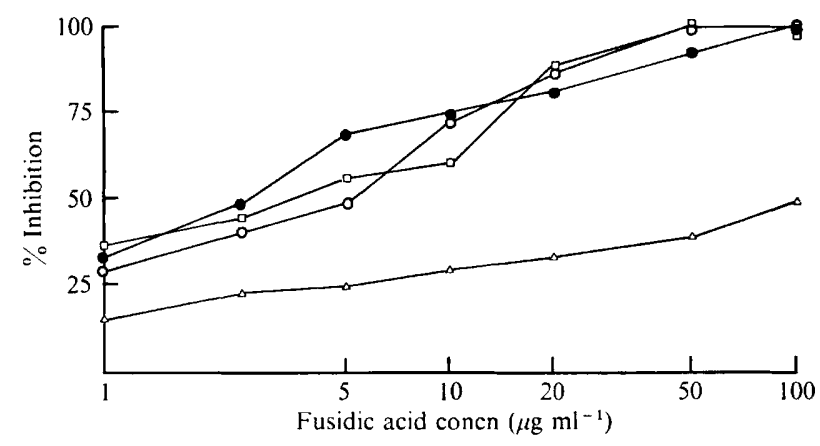

Fig. 3

Fig. 2. The effect of pre-incubation with fusidic acid on resistance to the antibiotic in UB4003, as measured by the inhibition of protein synthesis. Cultures of UB4003 were incubated with $(O)$ or without $(\bullet)$ fusidic acid $\left(0.5 \mu \mathrm{g} \mathrm{ml}^{-1}\right)$ for 2 generation times, and were then treated as described in Fig. $\mathrm{I}$.

Fig. 3. The effect of fusidic acid on protein synthesis (expressed as a percentage of the inhibition) in cell-free extracts prepared from: UB4OOI grown in the presence $(O)$ or absence $(O)$ of fusidic acid $\left(0.5 \mu \mathrm{g} \mathrm{ml}^{-1}\right)$; UB4002 $(\square)$; and UB4003 $(\triangle)$. Cell-free extracts were prepared and analysed as described by Lacey \& Chopra (I972).

of protein synthesis) for two generation times had no effect on resistance to fusidic acid during a subsequent challenge (data not shown).

Strain UB40OI showed increased resistance to fusidic acid after relatively short periods of exposure to the antibiotic (Fig. I). Exposure for 0.2 generation times $(5 \mathrm{~min}$ ) had little effect (Fig. I $a$ ); but after exposure for 0.5 generation times (I $4 \mathrm{~min}$ ), pre-exposed organisms were more resistant during subsequent challenge (Fig. I $b$ ). Maximal expression of increased resistance required exposure for approximately one generation time (27 min) (Fig. I c). Similar observations were made with UB4045 (data not shown).

Increased resistance to fusidic acid in UB400I probably did not depend on an increase in the number of plasmid copies per cell, since organisms grown in the absence of fusidic acid but in the presence of $\mathrm{CdCl}_{2}$ contained $6 \cdot 4 \pm 2 \cdot \mathrm{I} \%$ (five determinations) of their DNA in the $\mathrm{CCC}$ form, and organisms cultured in the presence of both $\mathrm{Cd}^{2+}$ and fusidic acid $\left(0.5 \mu \mathrm{g} \mathrm{ml}^{-1}\right.$ ) for many generations contained $5.5 \pm \mathrm{I} \cdot 3 \%$ (five determinations) of their DNA in the $\mathrm{CCC}$ form.

In contrast to UB40OI and UB4045, none of the spontaneous fusidic acid resistant derivatives (UB4003 to UB4006) showed increased resistance to the antibiotic-assessed by estimating its effect on protein synthesis-following exposure to sub-inhibitory concentrations ( $5 \%$ of the respective m.i.c.) for two generation times. Thus, for example, with UB4003 (Fig. 2) fusidic acid at $5 \mu \mathrm{g} \mathrm{ml}^{-1}$ inhibited protein synthesis by about $50 \%$, irrespective of whether or not organisms had been pre-exposed to the antibiotic. Data for derivatives UB4004, UB4005 and UB4006 are not shown.

\section{Effect of fusidic acid on protein synthesis in cell-free extracts}

Since resistance to fusidic acid may arise by modification of factor G, in Gram-negative organisms at least (Kinoshita et al., 1968; Bernardi \& Leder, 1970; Okura et al., 1970; Tanaka et al., 1971), it was important to assess whether similar changes were responsible for resistance in the fusidic acid resistant staphylococci. Accordingly, the sensitivity to 
fusidic acid of protein synthesis in cell-free systems from UB400I, UB4002 and UB4003 was compared (Fig. 3).

Protein synthesis in extracts from UB4002 (fusidic acid sensitive) was completely inhibited by fusidic acid at $50 \mu \mathrm{g} \mathrm{ml}^{-1}$, whereas extracts from UB4003 showed only $40 \%$ inhibition (Fig. 3). The spontaneous single-step mutation to fusidic acid resistance in UB4003 therefore resulted in the production of a protein-synthesizing system resistant to the antibiotic. Further experiments are required to establish whether factor $G$ was modified in UB4003. Protein synthesis in cell-free extracts prepared from UB400I was as sensitive to fusidic acid as synthesis in extracts from UB4002, irrespective of whether UB400I had been cultured in the presence of fusidic acid $\left(0.5 \mu \mathrm{g} \mathrm{ml}^{-1}\right)$ before the cell-free extracts were prepared (Fig. 3 ).

\section{Failure to demonstrate inactivation of fusidic acid by resistant strains}

Since the spontaneous fusidic acid resistant derivatives were probably all chromosomal mutants possessing modified protein-synthesizing components, there was no good reason for believing that they could inactivate the antibiotic. This view was supported by the failure to demonstrate fusidic acid inactivation by these mutants. Strains UB4003 to UB4006 were grown in the presence of fusidic acid $\left(\mathrm{I} \mu \mathrm{g} \mathrm{ml}^{-1}\right)$ at $37^{\circ} \mathrm{C}$ for $\mathrm{I} 8 \mathrm{~h}$ and the supernatants from these cultures were retained for bioassay of fusidic acid. To test for possible spontaneous decomposition of the antibiotic, uninoculated growth medium containing fusidic acid (I $\mu \mathrm{g} \mathrm{ml}^{-1}$ ) was treated as above and examined simultaneously with the culture supernatants. Although the assay system should be sufficiently sensitive to detect reductions in inhibitory activity of 10 to $15 \%$, there was no detectable inactivation of fusidic acid in any of the experiments (data not shown).

The data in the previous section are consistent with (at least) two possible mechanisms for plasmid-mediated resistance to fusidic acid. Resistance could be due either to changes at the cell surface resulting in exclusion of the antibiotic from the cell, or to enzymic destruction of the antibiotic. Incubation of growing cultures of UB400I with fusidic acid (I $\mu \mathrm{g} \mathrm{ml}^{-1}$ ), followed by bioassay (as above), failed to demonstrate inactivation of the antibiotic. However, it was still possible that plasmid-mediated fusidic acid resistance resulted from enzymic alteration of the antibiotic (not detected by the bioassay), since plasmid-mediated resistance may depend on the presence of antibiotic-metabolizing enzymes which do not result in gross inactivation of the antibiotic in the medium (Davies \& Benveniste, 1974; Lundback \& Nordstrom, 1974).

To assess this possibility, UB400I was cultured in the presence of $\left[\mathrm{II} \beta-{ }^{3} \mathrm{H}\right] \mathrm{fusidic}$ acid, the total radioactivity was extracted with chloroform, and the extract was subjected to thinlayer chromatography. In both solvents, culture extracts showed only one major peak which contained 89 to $90 \%$ of the recovered radioactivity and co-migrated with fusidic acid (Figs $4 a, c$ ). Additional minor peaks were observed, but these were also present in control samples in which either (i) $\left[{ }^{3} \mathrm{H}\right]$ fusidic acid was added to the bacterial culture immediately before chloroform extraction (Figs $4 b, d$ ), or (ii) $\left[{ }^{3} \mathrm{H}\right]$ fusidic acid was incubated at $37^{\circ} \mathrm{C}$ for $\mathrm{I} 8 \mathrm{~h}$ with growth medium containing no bacteria before chloroform extraction. The quantities of material in the minor peaks from (ii) were slightly greater than in (i) (data not shown).

The presence of the minor peaks in culture extracts was therefore probably unrelated to resistance. However, these experiments do not exclude the possibility that a derivative of fusidic acid was formed which co-migrated with fusidic acid. 


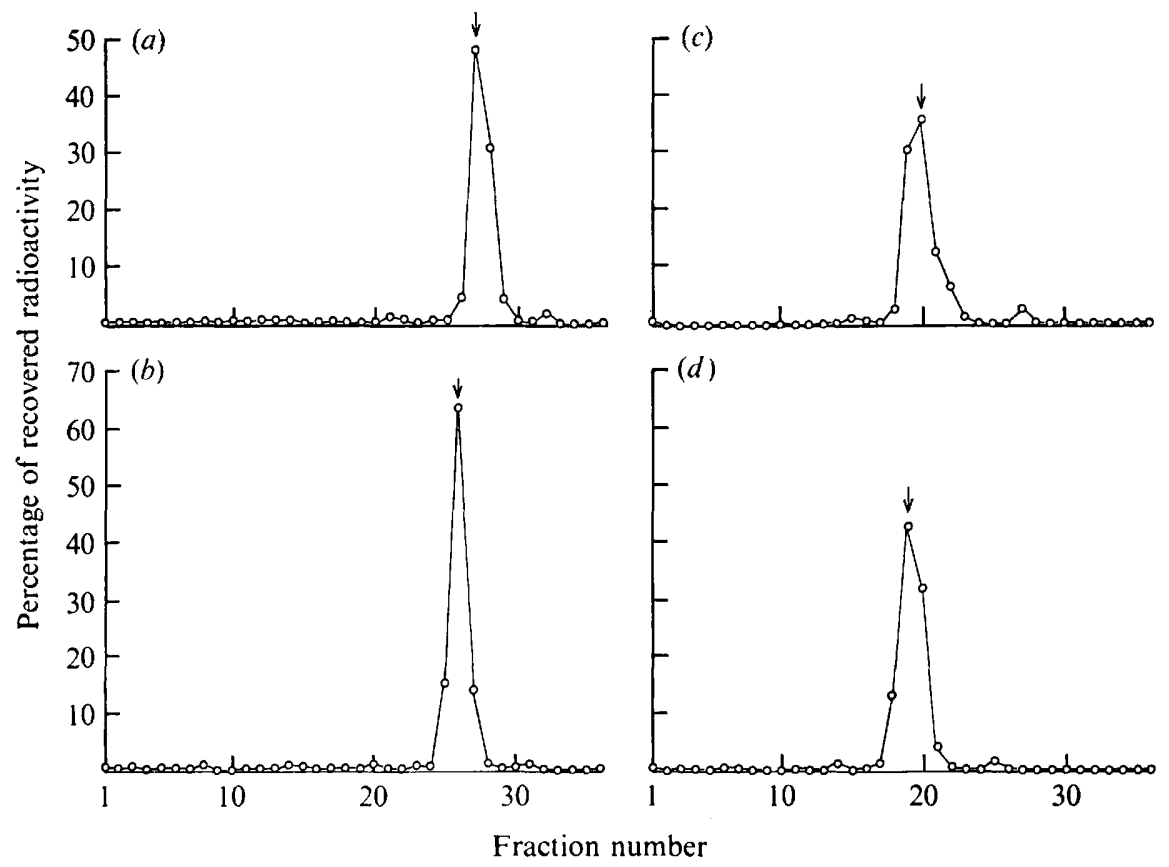

Fig. 4. Separation of chloroform extracts from cultures of UB400I containing labelled fusidic acid by thin-layer chromatography using $(a, b)$ solvent I or $(c, d)$ solvent 2. $(a, c)$. Separation of labelled material derived from a culture of UB4001 grown in the presence of [I $\left.13-{ }^{3} \mathrm{H}\right]$ fusidic acid (I $\mu \mathrm{g} \mathrm{ml}^{-1}$ ) for $\mathrm{I} 8 \mathrm{~h} .(b, d)$. Separation of labelled material derived from a culture of UB400I to which labelled fusidic acid (I $\mu \mathrm{g} \mathrm{ml}^{-1}$ ) was added immediately before chloroform extraction. The arrows denote the position of migration of authentic fusidic acid (see Methods).

Table 2. Ratios of phosphatidylglycerol to lysylphosphatidylglycerol in strains of $S$. aureus

$\begin{array}{lcc}\text { Culture } & \begin{array}{c}\text { Mean molar ratio, } \\ \text { PG :lysyl-PG* }\end{array} & \text { Significance level } \\ \text { UB400I } & 12 \cdot 3(\mathrm{I} 2) & t=5.62 P=<0.00 \mathrm{I} \\ \begin{array}{l}\text { UB400I, grown in the } \\ \text { presence of fusidic }\end{array} & 4 \cdot 2(8) & \\ \text { acid }\left(0.5 \mu \mathrm{g} \mathrm{m}^{-1}\right) & & \\ \text { UB4057 } & \mathrm{I0} \cdot 8(6) & t=14.3 P=<0.00 \mathrm{I} \\ \text { UB4045 } & 7 \cdot \mathrm{I}(8) & \end{array}$

* PG, phosphatidylglycerol; lysyl-PG, lysylphosphatidylglycerol. The number of determinations is given in parentheses.

\section{Changes in phospholipid composition associated with expression of plasmid-mediated resistance to fusidic acid}

Phosphatidylglycerol, lysylphosphatidylglycerol and cardiolipin (diphosphatidylglycerol) were the only phospholipids detected. The cardiolipin content remained essentially constant at 0.6 to $0.8 \%$ (mole fraction) of the total phospholipids for the cultures described in Table 2. However, the molar ratio of phosphatidylglycerol to lysylphosphatidylglycerol varied (Table 2). Induction of resistance to fusidic acid in UB400I was associated with a decrease in this ratio from $12 \cdot 3$ to $4 \cdot 2$. To determine whether expression of basal resistance 
to fusidic acid was also associated with a decrease in the ratio of phosphatidylglycerol to lysylphosphatidylglycerol, a strain possessing the plasmid region for fusidic acid resistance (UB4045) was compared with one in which this region had been deleted from the plasmid (UB4057). Currently this is the only pair of strains which are isogenic apart from variation in the plasmid region specifying fusidic acid resistance. Again, the ratio of phosphatidylglycerol to lysylphosphatidylglycerol was lower in the fusidic acid resistant strain (Table 2). Thus, expression of basal resistance to fusidic acid was also associated with a decrease in the ratio of these phospholipids.

\section{DISCUSSION}

The data suggest that two mechanisms of resistance to fusidic acid may occur in $S$. aureus. Mutation to resistance seems to result from modification of the protein synthetic apparatus. In contrast, plasmid-mediated resistance probably results from exclusion of antibiotic from the bacterial cell.

To establish that resistance to an antibiotic results from its exclusion from the cell, at least three criteria must usually be satisfied. (I) The target site remains susceptible to inhibition by the antibiotic in vitro. (2) The antibiotic is not inactivated. (3) There is decreased uptake of antibiotic by resistant bacteria. In the case of plasmid-mediated resistance to fusidic acid in $S$. aureus, the data presented in this paper appear to satisfy the first two criteria, but attempts to demonstrate decreased uptake of radioactively labelled fusidic acid by plasmid-carrying organisms (criterion 3) have failed. This was due principally to high binding of the antibiotic to membrane filters. Simila1 problems have been experienced by others (Bennett \& Maaloe, 1975). Attempts to destroy selectively the proposed permeability barrier by osmotic shock (Gale \& Llewellin, I970) have also failed (unpublished data).

The changes in phospholipid composition associated with the expression of both basal and induced resistance suggest that plasmid-mediated resistance is due to modification of the cell surface: this is consistent with the view that resistance results from exclusion of fusidic acid. Membranes in which the ionic head groups of the phospholipids are close to one another are more hydrophobic than those in which the head groups are separated, presumably reflecting closer packing of the acyl side chains of neighbouring phospholipid molecules (see Singer, I97I). Since lysylphosphatidylglycerol occupies a greater surface area per molecule than phosphatidylglycerol (Haest et al., 1972), the proximity of neighbouring acyl chains in membranes rich in lysylphosphatidylglycerol may be reduced, leading to an increase in the polarity of the membrane. Since the ability of an amphipathic molecule, such as fusidic acid, to pass through the membrane probably depends on the non-polar moiety being directed into the hydrophobic interior of the membrane, an increase in membrane polarity could impede passage of the fusidic acid molecule. However, a low ratio of phosphatidylglycerol to lysylphosphatidylglycerol is not an absolute requirement for resistance to fusidic acid since strain UB4002 (m.i.c. $0 \cdot 25 \mu \mathrm{g} \mathrm{ml}^{-1}$ ) had a phosphatidylglycerol to lysylphosphatidylglycerol ratio of $4 \cdot 6 \pm 0 \cdot 8$. Alternatively, therefore, the changes in phospholipid content might reflect alteration of lipid metabolism during or after integration of a plasmid-specified protein into the membrane which prevents passage of fusidic acid across the membrane. Attempts to identify such a membrane polypeptide have so far been unsuccessful.

Staphylococci having what are presumed to be chromosomal mutations to fusidic acid resistance often grow more slowly than their antibiotic-sensitive counterparts (Miller, I97I ; Pattison \& Mansell, I973). This may account for the relatively low incidence of naturally 
occurring staphylococci with chromosomal mutations to fusidic acid resistance since reduction in growth rate may affect the viability of bacteria in vivo (Garrod et al., 1973). However, in the staphylococci described here, chromosomal mutation to resistance to fusidic acid at between Io and $75 \mu \mathrm{g} \mathrm{ml}^{-1}$ did not significantly prolong the generation time beyond that of organisms possessing plasmid pUBIOI. Thus, factors other than changes in growth rate may contribute to the low clinical incidence of spontaneous (chromosomal) fusidic acid resistant mutants. Preliminary experiments (unpublished data) suggest that such mutants are less virulent for chick embryos than organisms in which resistance is mediated by plasmid genes. Further studies are required to establish the underlying molecular changes associated with the low incidence of chromosomal mutants in clinical isolates.

This work was supported by grants from the Medical Research Council to Professor M. H. Richmond for studies on bacterial plasmids. I am grateful to Dr W. O. Godtfredsen of Leo Pharmaceutical Products for advice and the generous provision of radioactively labelled fusidic acid.

\section{REFERENCES}

BENNETt, P. M. \& MAaloe, O. (1975). The effects of fusidic acid on growth, ribosome synthesis and RNA metabolism in Escherichia coli. Journal of Molecular Biology 90, 54I-56I.

Bernardi, A. \& Leder, P. (1970). Protein biosynthesis in Escherichia coli. Purification and characteristics of a mutant $\mathrm{G}$ factor. Journal of Biological Chemistry 245, 4263-4268.

Bligh, E. G. \& Dyer, W. J. (1959). A rapid method of total lipid extraction and purification. Canadian Journal of Biochemistry and Physiology 37, 9I I-9I7.

Bodley, J. W., Zieve, F. J., LIN, L. \& ZIEVE, S. T. (I969). Formation of ribosome-G factor-GDP complex in the presence of fusidic acid. Biochemical and Biophysical Research Communications 37, 437-443.

ChOPRA, I., BeNNETT, P. M. \& LACEY, R. W. (1973). A variety of staphylococcal plasmids present as multiple copies. Journal of General Microbiology 79, 343-345.

Davies, J. E. \& Benveniste, R. E. (1974). Enzymes that inactivate antibiotics in transit to their targets. Annals of the New York Academy of Sciences 235, I30-1 36.

Evans, R. J. \& WATERWORTH, P. M. (1966). Naturally occurring fusidic acid resistance in staphylococci and its linkage to other resistances. Journal of Clinical Pathology 19, 555-560.

Gale, E. F. \& Llewellin, J. M. (1970). Release of lipids from, and their effect on aspartate transport in osmotically shocked Staphylococcus aureus. Biochimica et biophysica acta 212, 546-549.

Garrod, L. P., Lambert, H. P. \& O’Grady, F. (1973). Antibiotics and Chemotherapy, 4th edn. Edinburgh and London: Churchill Livingstone.

Grove, D. C. \& Randall, W. A. (1955). Assay Methods of Antibiotics, p. 9I. New York: Medical Encyclopaedia Inc.

Haest, C. W. M., De Gier, J., Op Den Kamp, J. A. F., Bartels, P. \& Van Deenen, L. L. M. (I972). Changes in permeability of Staphylococcus aureus and derived liposomes with varying lipid composition. Biochimica et biophysica acta $\mathbf{2 5 5}, 720-733$.

Kinoshita, T., Kawano, G. \& Tanaka, N. (1968). Association of fusidic acid sensitivity with $G$ factor in a protein synthesising system. Biochemical and Biophysical Research Communications 33, 769-773.

LACEY, R. W. (I975). Antibiotic resistance plasmids of Staphylococcus aureus and their clinical importance. Bacteriological Reviews 39, I-32.

LACEY, R. W. \& ChOPRA, I. (I972). Evidence for mutation to streptomycin resistance in clinical strains of Staphylococcus aureus. Journal of General Microbiology 73, 175-180.

LACEY, R. W. \& Chopra, I. (1974). Genetic studies of a multi-resistant strain of Staphylococcus aureus. Journal of Medical Microbiology 7, 285-297.

LACEY, R. W. \& GRINSTED, J. (1972). Linkage of fusidic acid resistance to the penicillinase plasmid in Staphylococcus aureus. Journal of General Microbiology 73, 501-508.

LACEY, R. W., LEWIS, E. \& RoSDAHL, V. T. (1974). Evolution of plasmids in vivo in a strain of Staphylococcus aureus. Journal of Medical Microbiology 7, 1 I 7-1 25.

LACEY, R. W. \& RosDAHL, V. T. (1974). An unusual 'penicillinase plasmid' in Staphylococcus aureus: evidence for its transfer under natural conditions. Journal of Medical Microbiology 7, I-9.

Lowbury, E. J. L., CAson, J. S., JACKson, D. MACG. \& Miller, R. W. S. (1962). Fucidin for staphylococcal infection of burns. Lancet ii, $478-480$.

LuNDBACK, A. K. \& NoRdSTROM, K. (I974). Effect of R-factor-mediated drug metabolising enzymes on survival of Escherichia coli K-I2 in the presence of ampicillin, chloramphenicol or streptomycin. Antimicrobial Agents and Chemotherapy, 5, 492-499. 
Miller, G. R. (I97I). Fusidic acid resistant staphylococci. Antonie van Leeuwenhoek 37, 313-31 7.

MinNIKIN, D. E. \& AbDolrahimzadEH, H. (I97I). Thin-layer chromatography of bacterial lipids on sodium acetate-impregnated silica gel. Journal of Chromatography 63, 452-454.

Okura, A., Kinoshita, T. \& TANaka, N. (1970). Complex formation of fusidic acid with G factor, ribosome and guanosine nucleotide. Biochemical and Biophysical Research Communications 41, I545-I 550.

Pattison, J. R. \& Mansell, P. E. (I973). Fucidin-resistant staphylococci in current hospital practice. Journal of Medical Microbiology 6, 235-244.

RichmaN, N. \& BoDley, J. W. (I972). Ribosomes cannot interact simultaneously with elongation factors EF Tu and EF G. Proceedings of the National Academy of Sciences of the United States of America 69, 686-689.

SINGER, S. J. (1971). The molecular organisation of biological membranes. In Structure and Function of Biological Membranes, pp. I45-222. Edited by L. I. Rothfield. New York: Academic Press.

SkIPSKI, V. P. \& Barclay, M. (I969). Thin layer chromatography of lipids. In Methods in Enzymology, vol. 14, pp. 530-598. Edited by J. M. Lowenstein. New York: Academic Press.

SNYDER, F. \& STEPHENS, N. (I962). Quantitative carbon-I4 and tritium assay of thin-layer chromatography plates. Analytical Biochemistry 4, I 28-I3I.

Tanaka, N., Kawano, G. \& Kinoshita, T. (I97I). Chromosomal location of a fusidic acid resistance marker in Escherichia coli. Biochemical and Biophysical Research Communications 42, 564-567. 